\title{
Compensation for Time Value as Part of Adequate Protection During the Automatic Stay in Bankruptey
}

Under state law, a secured creditor $^{1}$ has the right to repossess and sell the property securing a debt if the debtor defaults. ${ }^{2}$ The debtor's filing of a petition in bankruptcy ${ }^{3}$ under the Bankruptcy Reform Act of 1978" (the "Code"), however, automatically stays enforcement of the secured creditor's state default rights. ${ }^{5}$ The automatic stay suspends the terms of the original loan and in effect forces the creditor to make a new loan equal to the amount of the secured claim. ${ }^{6}$ By providing secured creditors two forms of protection, however, the Code recognizes the state-law rights ${ }^{7}$ of secured creditors to a first claim on the collateral securing their loans. First, from the time the debtor files for bankruptcy until a court confirms a reorganization plan $^{8}$ (the effective period of the auto-

1 There are several types of secured creditors; a large and important group consists of creditors who have perfected security interests under Article 9 of the Uniform Commercial Code. U.C.C. § 1-201(37) (1972) defines a "security interest" as "an interest in personal property or fixtures which secures payment or performance of an obligation." All states except Louisiana have adopted Article 9. For a symposium discussion of the differences between Louisiana law and Article 9, see Security Rights in Movables Under the Uniform Commercial Code and Louisiana Law-A Transactional Comparison, 40 TUL. L. REv. 744 (1966).

2 The events that constitute default by a debtor are determined by the security agreement. See U.C.C. \$ 9-501(1) (1972). When a debtor is in default, the secured party has the rights and remedies provided in part 5 of Article 9 of the U.C.C., including the right to foreclose. $I d$.

See 11 U.S.C. $\$ \S 301,362$ (a) (Supp. V 1981) (a voluntary case is commenced by the debtor's filing a petition, which operates as an automatic stay). The voluntary case is the most common type of case, although it is also possible for creditors to file a petition under certain circumstances enumerated in $i d$. $\S 303(\mathrm{~b})$. These are known as involuntary cases. Id. $\S 303(a)$. The filing of a petition in an involuntary case also operates as an automatic stay. Id. $\$ 362(\mathrm{a})$.

' Pub. L. No. 95-598, 92 Stat. 2549 (codified as Title 11 of U.S.C. (Supp. V 1981)). The Code revised Title 11 of the United States Code, changed sections of Title 28 relating to bankruptcy courts, and included other conforming amendments and transition procedures. The Code took effect on October 1, 1979. See 11 U.S.C.A. preface (West Supp. 1982).

s 11 U.S.C. \$ 362 (Supp. V 1981). Section 362(a) enumerates the actions stayed; subsection (b) lists exceptions.

- See generally id. $\$ 506$ (a) (defining the secured claim as the lesser of the value of the collateral securing the debt and the amount of the debt).

See U.C.C. $\$ \S 9-201,-301,-312$ (1972) (priority of secured parties).

- A reorganization plan must be confirmed by the court. The court may confirm a plan 
matic stay), ${ }^{\circ}$ the Code requires that the court provide "adequate protection" of secured claims. ${ }^{10}$ Second, the Code requires that a court give to any secured creditor who objects to a reorganization plan property whose present value equals the value of his secured claim. ${ }^{11}$

This comment focuses on the first type of protection and asks whether "adequate protection" includes compensation for the time value of secured claims while the stay is in effect. ${ }^{12}$ The issue arises

if, inter alia, each holder of a claim has accepted the plan or if each holder will receive "property of a value, as of the effective date of the plan, that is not less than the amount that such holder would have received [in a Chapter 7 liquidation]." 11 U.S.C. § 1129(a)(7)(A) (Supp. V 1981).

- The Code lifts the stay upon discharge. Id. $\S 362(c)(2)$. The reorganization plan effects a discharge. Id. $\S 1141$ (d). The discharge in a Chapter 13 proceeding is provided for in id. $\S 1328$; the discharge in a Chapter 7 proceeding is provided for in $i d . \S 727$.

10 "Adequate protection" must be provided in every situation in which the secured creditor is not permitted to foreclose, see id. $\$ 362(d)(1)$; the usual situation, however, is a reorganization. Adequate protection must be provided even when the reorganization plan will provide for sale of the business as a going concern and use of the proceeds to pay the creditors. If adequate protection is not provided, the court, at the request of the secured creditor, must lift the stay or make such modifications or conditions as will provide the creditor with adequate protection. Id.

Section 361 provides two nonexclusive ways to provide adequate protection, and it allows the court to fashion adequate protection by such other means as will result in the secured creditor's realizing the "indubitable equivalent" of his claim. Id. § 361 . The court may not, however, fashion adequate protection by granting the secured creditor an administrative priority. Id. $\S 361(3)$. For a discussion of the administrative priority, see infra notes 33-40 and accompanying text. The lack of precise substantive content in the adequate protection definition is deliberate; the drafters of the Code felt that a more defined limitation on the means that courts may use to provide adequate protection would be inappropriate. See S. Rep. No. 989, 95th Cong., 2d Sess. 54 (1978) [hereinafter cited as Senate Report], reprinted in 1978 U.S. CodE CoNG. \& AD. News 5787, 5840; H.R. REP. No. 595, 95th Cong., 1st Sess. 339 (1977) [hereinafter cited as HouSE REPORT], reprinted in 1978 U.S. CoDE Cong. \& AD. NEws 5963, 6295.

1111 U.S.C. $\S 1129(a)(7)$ (Supp. V 1981). If a class of secured creditors dissents, it is entitled to the somewhat greater protections of the "cram-down" provisions. See infra note 19.

If a plan is not confirmed within $\mathbf{1 8 0}$ days of the debtor's filing of a petition or if the debtor does not submit a plan within 120 days of the filing, "[a]ny party in interest," including a creditor, may submit his own reorganizaton plan. 11 U.S.C. \$1121(c) (Supp. V 1981). These deadlines may be moved up or extended at the discretion of the court. Id. §1121(d). In the event of an "inability to effectuate a plan" or a "denial of confirmation of every proposed plan," a reorganization proceeding generally may be converted to a liquidation proceeding. Id. \& $1112(\mathrm{~b})(2),(5)$.

12 "Compensation for time value" does not necessarily mean paying cash. Compensation may be provided by (1) paying cash, (2) increasing the value of the allowed secured claim and providing additional liens to secure such increase, or (3) providing the indubitable equivalent of (1) or (2). See 11 U.S.C. \$ 361 (Supp. V 1981); supra note 10.

The term "time value" as used in this comment is the amount one would pay to have use of the money for a period of time (including premiums one would pay to account for the risks of nonpayment and inflation). On the use of this analysis to calculate interest rates in 
whenever an automatic stay prevents exercise of default rights against property essential to reorganization. ${ }^{13}$ The Code does not explicitly answer the question, and the bankruptcy courts are divided. ${ }^{14}$

The decision whether to provide interest on secured claims is of substantial practical importance because it affects the cost and availability of secured credit. ${ }^{15}$ Moreover, the current disarray in

other contexts, see R. Brealey \& S. Myers, Principles of Corporation Finance 448-54 (1981); R. Posner, Economic ANalysis of the LAW § 6.13, at 147 (2d ed. 1977) (calculating interest rate for discounting award for damages for loss of earning capacity); with regard to the calculation of this amount, see infra notes 76-84 and accompanying text.

${ }^{13}$ If the property is not essential to the reorganization and the debtor has no equity in the property, the secured creditor can have the stay lifted. 11 U.S.C. $\S 362$ (d)(2)(B) (Supp. V 1981).

The debtor in possession may, of his own accord, provide adequate protection by remaining current on all payments of principal and interest to the secured creditor. In general, few debtors in bankruptcy are able to avail themselves of this opportunity, for if they could there would be no reason for bankruptcy. There are exceptions, however, such as Manville Corporation, which filed a Chapter 11 petition despite financial health, to remove tort litigation over asbestosis to bankruptcy court. See An Asbestos Bankruptcy, NEwSwEEK, Sept. 6, 1982 , at 54.

14 Some courts for various reasons have denied compensation for the time value of secured claims during the automatic stay. See, e.g., In re South Village, Inc., 9 Bankr. Ct. Dec. (CCR) 1332, 1338-39 (Bankr. D. Utah 1982); In re Pine Lake Village Apartment Co., 19 Bankr. 819, 826-28 (Bankr. S.D.N.Y. 1982); In re BBT, 11 Bankr. 224, 231 n.12 (Bankr. D. Nev. 1981) (under Code $§ 502(b)(2)$ there may be no postpetition interest on undersecured claims); In re American Mariner Indus., 10 Bankr. 711, 712-13 (Bankr. C.D. Cal. 1981) (Code $\S 506$ (b), by negative implication, denies interest to undersecured creditors); General Motors Acceptance Corp. v. Anderson, 6 Bankr. 601, 608 (Bankr. S.D. Ohio 1980) (interest precluded by Code $\S 506(\mathrm{~b})$ ). Some courts, however, have recognized that the failure to compensate for time value results in a substantial diminution of the secured creditor's interest in the collateral. See, e.g., In re Monroe Park, 17 Bankr. 934, 939-41 (D. Del. 1982); In re Victory Constr. Co., 9 Bankr. 570, 573-74 (Bankr. C.D. Cal. 1981); In re Riveroak Inv. Corp., 9 Bankr. 1, 2 (Bankr. S.D. Fla. 1980); In re Anchorage Boat Sales, Inc., 4 Bankr. 635, 643 (Bankr. E.D.N.Y. 1980). Frequently, courts never reach the question of compensation for time value because they find other reasons for granting relief from the automatic stay. See, e.g., In re Lackow Bros., 16 Bankr. 566, 570 (Bankr. S.D. Fla. 1981) (where debtor has no equity in the property and has proposed no means of adequate protection, relief will be granted); In re Hudson Ambulance Servs., Inc., 11 Bankr. 860, 866 (Bankr. S.D.N.Y. 1981) (equity cushion inadequate to protect IRS if IRS is required to turn over seized property); In re Thomas Parker Enters., 10 Bankr. 783, 789 (Bankr. D. Conn. 1981) (insufficient equity in collateral); In re Pittman, 8 Bankr. 299, 302 (Bankr. D. Colo. 1981) (failure of debtor to show retention of collateral necessary to reorganization); In re Pittman, 7 Bankr. 760, 76263 (Bankr. S.D.N.Y. 1980) (failure by debtor to pay property taxes and insurance on collateral property).

16 If secured creditors know that they will not be compensated for time value during the stay, they will account for this risk of being forced to extend an interest-free loan in either of two ways. First, they may insist on an interest premium on the original loan to account for the risk of the forced, interest-free loan. Second, they may obtain sufficient collateral to ensure that they will remain fully secured if the debtor files a petition in bankruptcy: contractual interest continues to run during the stay if the creditor is fully secured. 
the case law makes creditors' rights in bankruptcy uncertain, and this uncertainty increases the costs of both secured and unsecured credit. ${ }^{16}$ An absolute rule favoring or opposing interest payments on secured claims would eliminate these costs of uncertainty. After reviewing the Code's history, the policies underlying the Code, and the arguments courts have presented for both rules, this comment

See 11 U.S.C. § 506(b) (Supp. V 1981). This second method of compensating for the court's denial of time value compensation, however, is not fool-proof for two reasons. First, the collateral may depreciate during the period between the signing of the contract and the filing of the petition. Second, there is a risk that the bankruptcy court will undervalue the collateral. This latter risk is inherent in the Code's provisions allowing the bankruptcy court to value collateral for purposes of $i d$. § 506(a). See generally, SENATE REPORT, supra note 10, at 68, reprinted in 1978 U.S. CODE CoNG. \& AD. NEws at 5854 (discussing court's power to value property). The bankruptcy valuation process generally results in the undercompensation of the secured creditors. See Jackson, Bankruptcy, Non-Bankruptcy Entitlements, and the Creditor's Bargain, 91 Yale L.J. 857, 874-75 \& n.80 (1982) (noting problem and suggesting that market value be used).

Scholars generally assume that allowing secured creditors to contract for the priority of security interests decreases the total cost of credit. See infra note 17. If this assumption is correct, then a rule denying compensation for time value during the stay can dilute the costsaving resulting from secured credit in several ways. If secured creditors need to take extra collateral to increase their chances of being fully secured in the event of bankruptcy, the debtor will have less property available to secure additional loans, and fewer creditors will be able to avail themselves of secured credit to reduce borrowing costs. Similarly, if secured creditors add a premium to account for the risk of not being able to foreclose on their collateral, the costs of credit will rise overall, though it is likely that a reduction in the cost of unsecured credit will partially offset the increased cost of secured credit.

One explanation of the cost-saving caused by secured credit follows from a monitoring theory. The theory is that secured credit is cheaper than unsecured credit because monitoring costs are lower; that is, unsecured creditors must monitor all aspects of the debtor's operation to prevent misbehavior, but the secured creditor need only be sure that the debtor does not dispose of the asset securing the loan. See Jackson \& Kronman, Secured Financing and Priorities Among Creditors, 88 YaLe L.J. 1143, 1149-61 (1979); Schwartz, Secured Interests and Bankruptcy Priorities: A Review of Current Theories, 10 J. LEgAL Stud. 1, 9-14 (1981). One can easily see that a secured creditor who was aware that he would not be completely compensated for his secured claim would have to be more concerned with the possibility of bankruptcy than a secured creditor who knew he would be fully compensated. As a result, the creditor would have to pay closer attention to the operation of the borrower's business as a whole, rather than merely to the disposition of the collateral. Different explanations for the deleterious impact of denying time value compensation on the cost of credit could be made based on other explanations for the cost-reduction effect of secured credit. See Schwartz, supra, at 14-33.

10 Secured credit is generally thought to effect a reduction in the cost of credit to debtors because secured creditors know in advance what will occur in the event of the debtor's bankruptcy. See Schwartz, supra note 15, at 24-27. The current disarray in the case law disrupts the presumption under which secured creditors proceed regarding part of the value of their claim-the part represented by the time value of their claim during the automatic stay period. The result is a reduction in the savings secured credit is thought to effect. The conflicting case law also increases the cost of credit because litigation over the issue of interest during the automatic stay results in costs that decrease the value of the debtor's estate from which unsecured claims are paid. Unsecured creditors who know in advance that litigation is likely to arise will protect themselves by charging more for extending credit. 
concludes that compensation for the time value of secured claims should always be included as part of the statutory "adequate protection."17

\section{The Case for Paying Interest During the Automatic Stay}

The history of the term "adequate protection" and the Code's policy toward secured credit provide strong evidence that Congress intended to compensate secured creditors completely. "Adequate protection" first appeared in section 77B of the Bankruptcy Act of $1898^{18}$ (the "old Act"), the predecessor of the current Code. The old Act mandated that a secured creditor be given adequate protection in the event that a reorganization plan was confirmed over his objection, ${ }^{19}$ a situation commonly referred to as "cram-down." In In re Murel Holding Corp., ${ }^{20}$ the leading case defining adequate protection under the old Act, the Second Circuit held that secured creditors would be adequately protected only if payments under the plan were "completely compensatory"; the payments must include compensation for the time value of the secured claims. ${ }^{21}$

17 Because denying time value compensation increases the cost and reduces the availability of secured credit, one would think that an absolute rule granting such compensation is desirable. Such a conclusion assumes the social utility of secured credit. Although the availability of secured credit generally is considered socially beneficial because it is thought to reduce the total cost of secured credit to debtors, see generally Jackson \& Kronman, supra note 15; Schwartz, supra note 15; D. Baird \& T. Jackson, Cases, Problems and Materials on Security Interests in Personal Property 4-1 to 4-14 (1982) (unpublished manuscript) (on file with The University of Chicago Law Review), there is some contention that it does not have this cost-reducing effect, see Schwartz, supra note 15, at 7-30.

18 Pub. L. No. 55-171, 30 Stat. 544 (1898). Section 77B was added by Act of June 7, 1934, Pub. L. No. 73-296, § 1, 48 Stat. 911,912 (codified as amended at 11 U.S.C. $\S 616$ (1976) (repealed 1978)). The old Act was replaced by the Code, effective October 1, 1979. See supra note 4.

19 Section 616 of the old Act, 11 U.S.C. $\$ 616$ (1976) (repealed 1978), required "adequate protection" of dissenting creditors. Under the Code, adequate protection under $\$ 361$ refers to the protection of secured creditors during the stay, see infra text accompanying note 23; the rights of dissenting creditors in cram-down are spelled out in 11 U.S.C. $\$$ 1129(a)(7) (Supp. V 1981). A dissenting class of secured creditors is entitled either (1) to a promise of cash payments with a present value equal to the amount of its secured claims and to retain its liens or (2) to the "indubitable equivalent of its secured claim." Id. \& 1129(b)(2)(A)(i), (iii). As a practical matter, each secured creditor constitutes a class and thus is entitled to these greater protections. Trost, Business Reorganizations Under Chapter 11 of the New Bankruptcy Code, 34 Bus. LAw. 1309, 1327 (1979).

2075 F.2d 941 (2d Cir. 1935).

21 The Murel Holding opinion in pertinent part reads:

It is plain that "adequate protection" must be completely compensatory; and that payment ten years hence is not generally the equivalent of payment now. Interest is indeed the common measure of the difference, but a creditor who fears the safety of his principal will scarcely be content with that; he wishes to get his money or at least the property. We see no reason to suppose that the statute was intended to deprive him of that 
Judge Learned Hand based this holding on "constitutional limitations" on Congress's power to force secured creditors to accept an undercompensatory reorganization plan. ${ }^{22}$

In contrast, adequate protection under the current Code refers not to cram-down protection, but to the rights of the secured creditor in the event that the debtor remains in possession of the collateral during the stay. ${ }^{23}$ There is no constitutional requirement that courts compensate secured creditors during a stay, under reasonable terms, of the exercise of their default rights. ${ }^{24}$ The Murel

in the interest of junior holders, unless by a substitute of the most indubitable equivalence.

Id. at 942 . It is significant that adequate protection under the Code during the automatic stay requires that secured creditors retain their existing liens or receive cash payments, a substitute lien, or the "indubitable equivalent." See 11 U.S.C. \& 361 (Supp. V 1981). This likeness in phrasing to the passage from Murel Holding supports the argument that Congress intended the same definition of "adequate protection," which includes compensation for time value, to apply under the Code. See infra notes $22-26$ and accompanying text. The phrase "indubitable equivalent" also appears in the Code in the context of cram-down. 11 U.S.C. $\$ 1129(b)(2)(A)(i i i)$ (Supp. V 1981).

2275 F.2d at 942.

${ }^{23}$ See supra notes 8-10 and accompanying text.

2، In Louisville Joint Stock Land Bank v. Radford, 295 U.S. 555 (1935), the Supreme Court struck down $\S 75(\mathrm{~s})$ of the old Act, known as the first Frazier-Lemke Act, Pub. L. No. $73-486,48$ Stat. 1289 (1934). The operative provision, § $75(\mathrm{~s})(7), 48$ Stat. at 1291 , provided for a five-year stay of foreclosure, with the debtor remaining in possession subject to the control of the court so long as he paid "reasonable rentals" for distribution to the secured and unsecured creditors. At any point within five years, the debtor was entitled to buy the property by paying into the court the appraised value of the property. The Act applied only retrospectively. The Court reasoned that $\S 75(\mathrm{~s})(7)$ denied the secured creditor five rights: (1) the right to retain the lien until the debt was paid in full; (2) the right to realize on the collateral through judicial sale; (3) the right to determine the time of the sale, subject to the supervision of the court; (4) the right to place a bid up to the amount of the debt at the judicial sale in order to protect his investment; and (5) the right to control the property during default subject to the supervision of the court. 295 U.S. at 594-95. The Court stated:

Strong evidence that the taking of these rights from the mortgagee effects a substantial impairment of the security is furnished by the occurrences in the Senate which led to the adoption there of the amendment to the bill declaring that the Act shall apply only to debts existing at the time this Act becomes effective.

Id. at 595 .

In Wright v. Vinton Branch of the Mountain Trust Bank, 300 U.S. 440 (1937), the Court upheld a modified version of the Frazier-Lemke Act, Pub. L. No. 74-384, 49 Stat. 942 (1935) (expired by its own terms). The Act provided for a three-year stay, during which the creditor's liens would remain in effect. The debtor could retain possession, subject to the payment of a reasonable rental, to be used for maintenance, taxes, and payment of the secured or unsecured debt. The stay was also subject to the authority of the court to order the debtor to make payments on the principal of the secured debt. Throughout the threeyear stay, the debtor could purchase the property for its appraised value. The Court held that three of the rights deemed impaired in Radford were protected by this Act: the right of the creditor to retain his liens, the right of the creditor to realize on the property through judicial sale, and the right of the creditor to place a bid up to the amount of the debt at the sale. Vinton Branch, 300 U.S. at 458-59. The subsequent holding of the Court in Wright v. 
Holding definition of adequate protection, therefore, is not constitutionally required under the Code. The legislative history of the Code, however, shows that Congress believed that adequate protection for secured creditors was justified for policy reasons, ${ }^{25}$ and a review of the policies underlying the Code indicates that Congress did not intend to alter Murel Holding's definition ${ }^{28}$ of the term or to deny secured creditors their first claim on the collateral under state law. ${ }^{27}$

Union Cent. Life Ins. Co., 311 U.S. 273 (1940), however, eviscerated Vinton Branch's distinctions between the two Frazier-Lemke Acts. The Court held that the debtor's right to purchase the property at its appraised value was superior to the creditor's right to a judicial sale. Id. at 280-81. Union Central thus undermined the requirement of a judicial sale and the right to place a bid up to the amount of the debt. The third critical right in Vinton Branch, the retention of the lien protected under the second Frazier-Lemke Act, was rendered a meaningless formalism because the lien could be discharged by payment of the appraised value.

The substantive provisions of the automatic stay under 11 U.S.C. $\S 361$ (Supp. V 1981) are, even without compensation for time value, more protective of the creditor's rights than those upheld in Vinton Branch and Union Central. Although it could be argued that, because of today's high interest rates, the creditor's substantive rights are more severely impaired under the Code's stay than they were under that of the second Frazier-Lemke Act, no court has held that this impairment rises to the level of a deprivation prohibited under the Constitution.

${ }^{25}$ See House Report, supra note 10, at 339, reprinted in 1978 U.S. Code Cong. \& AD. NEws at 6295 . The legislative history does not specifically address whether adequate protection must include time value compensation. There is only one explicit reference to the amount to be paid as adequate protection, and it is in the discussion of In re Bermec Corp., 445 F.2d 367 (2d Cir. 1971). See Senate Report, supra note 10, at 54, reprinted in 1978 U.S. Code Cong. \& AD. News at 5840. In Bermec, the Second Circuit held that a debtor met the adequate protection requirement by paying cash to the secured creditor equal to the "economic depreciation" of the collateral. 445 F.2d at 369. Congress made cash payments one method of providing adequate protection under the Code, see supra note 19, but specifically reserved the question of "whether the payments offered [in Bermec] were adequate to compensate the secured creditors for their loss." SENATE REPORT, supra note 10, at 54, reprinted in 1978 U.S. Code Cong. \& AD. News at 5840. But see House REPORT, supra note 10, at 339, reprinted in 1978 U.S. CoDe Cong. \& AD. NEws at 6296 (referring to the mechanism of providing cash payments as adequate protection as derived from In re Yale Express Sys., 384 F.2d 990 (2d Cir. 1967), not from Bermec).

20 When the Code was enacted, courts were still applying Murel Holding's definition of adequate protection. See, e.g., In re Schwab Adams Co., 463 F. Supp. 8, 12 (S.D.N.Y. 1978); In re Cartwright Land Assocs., 3 Bankr. 277, 279 (Bankr. S.D.N.Y. 1980). See also Bamerical Mortgage \& Fin. Co. v. Paradise Boat Leasing Corp. (In re Boat Leasing Corp.), 2 Bankr. 482, 484 (Bankr. D.V.I. 1979) (citing Murel Holding).

27 When Congress's primary concern has been debtor protection, it has at times chosen to exercise its power to impose uncompensated stays of foreclosures on creditors. For example, during the Great Depression Congress enacted legislation meant to relieve farmers by imposing an uncompensated three-year stay of foreclosures on farmland mortgagees. The farmers' relief measures were known as the Frazier-Lemke Acts. See supra note 24.

In passing this legislation, Congress was aware of the harmful effects the uncompensated stay would have on the availability of secured credit, yet it deliberately chose to bear those costs to prevent foreclosures. With regard to the first Frazier-Lemke Act, see 78 Cong. 
The House and Senate Reports concerning the Code both note an intent to harmonize bankruptcy law with the realities of a modern credit economy, an important aspect of which is the general availability of secured credit under Article 9 of the Uniform Commercial Code. ${ }^{28}$ More particularly, the House Report speaks of adequate protection as providing the secured creditor "in value essentially what he bargained for."29 The secured creditor bargains for the right to repossess the collateral at the time of default and thereby to collect the value of the collateral up to the amount of the debt. ${ }^{30}$ Hence payment of this amount immediately following the filing of the petition would give the secured creditor essentially the value for which he bargained. Payment of the same amount at a later time, however, is worth less ${ }^{31}$ and therefore does not provide the secured creditor with full compensation for surrendering his default rights. Thus, failure to compensate the secured creditor for the time value of his secured claim deprives him of the benefit of his bargain.

Congress's resolution of a controversial adequate protection issue further evidences the policy of protecting the first claim of secured creditors. In In re Yale Express Systems, ${ }^{32}$ a case under the old Act, the Second Circuit held that when rental payments to secured creditors would drastically impair the debtor's chance for successful reorganization, the secured creditors could be forced to accept "equitable consideration in the reorganization plan" -essentially an administrative priority-as protection of their inter-

REc. 12,074-75 (1934) (remarks of Sen. Bankhead), 12,075 (remarks of Sen. Fess), 12,137 (remarks of Rep. Peyser). With regard to the second Frazier-Lemke Act, see 79 Cong. REc. 13,635-40 (1935) (debate between Sen. Bailey and several other senators). Congress held a different view of secured credit, however, when it enacted the new Code. See infra notes 2845 and accompanying text.

${ }^{28}$ See House Report, supra note 10 , at $3-4,5$, reprinted in 1978 U.S. Code CoNG. \& AD. News at 5965, 5966 (bankruptcy law should be brought into harmony with the growth of consumer and commercial credit and with the "nearly universal" adoption of the Uniform Commercial Code); see also SENATE REPORT, supra note 10, at 2-3, reprinted in 1978 U.S. Code Cong. \& AD. News at 5788 (same).

29 House REport, supra note 10, at 339, reprinted in 1978 U.S. Code Cong. \& AD. NEws at 6295 .

30 Collection of the value of the collateral up to the amount of the debt is the extent of the secured creditor's rights under Article 9 of the U.C.C. See U.C.C. $\$ \$ 9-501(3)(1),-502(2)$, -504(2) (1972) (requiring secured parties to account to the debtor for any surplus from sale of collateral). The Code adopts the same rule. See 11 U.S.C. § 506(1) (Supp. V 1981) (determining amount of secured claims); id. $\S 725$ (disposition of property subject to a lien in liquidation).

31 See infra note 44 and accompanying text.

32384 F.2d 990 (2d Cir. 1967). 
ests. ${ }^{33}$ An administrative priority is less desirable than a security interest because secured creditors are entitled to payment from sale of their collateral, ${ }^{34}$ but administrative claimants are paid out of property remaining in the debtor's estate following payment of secured claims. ${ }^{35}$ The Yale Express rule thus forced secured creditors to bear some of the risk that the reorganization would fail and that in a subsequent liquidation there would be insufficient property remaining to pay administrative claims in full..$^{36}$

The Commission on the Bankruptcy Laws of the United States recommended that Congress adopt a modified version of the Yale Express rule in $1973,{ }^{37}$ and the House followed the recommendation in its version of the Bankruptcy Reform Act. ${ }^{38}$ The Senate removed the provision and substituted a prohibition on the use of an administrative priority as adequate protection. ${ }^{39}$ The final version of the Code included the Senate's prohibition on the use of an administrative priority as adequate protection and added section 507(b), which creates a "superpriority" on the unencumbered assets of the debtor's estate as an additional protection for secured creditors. ${ }^{40}$ The rejection of the Yale Express rule suggests that Congress chose not to impose the risk of the failure of reorganization on secured creditors, ${ }^{41}$ even though such imposition

ss Id. at 992.

34 See supra note 30 for the limitations on a secured creditor's right to his collateral.

36 11 U.S.C. $\$ 726(a)(1)$ (Supp. V 1981). In reorganization, an administrative claimant is also in a position inferior to that of a secured creditor because the property to which each is entitled under the reorganization plan is determined by what each would receive in liquidation. See id. § 1129(a)(7).

38 See infra notes $42-45$ and accompanying text (comparing the undercompensatory effects of the Yale Express rule with denial of compensation for time value during the stay).

${ }^{37}$ H.R. Doc. No. 137, 93d Cong., 1st Sess. 236 (pt. 2) (1973). The Commission's note recommended that one of the "[c]onditions which may be imposed by the court" on the creditor should be the acceptance of "a priority if it is clear that the proceeds of the liquidation . . . available to pay the claim will be sufficient." Id. at 237.

ss H.R. 8200, 95th Cong., 1st Sess., \& 361 (1977), reprinted in The Bankruptcy Reform Act of 1978: Hearings on S. 2266 and H.R. 8200 Before the Subcomm. on Improvements in the Judicial Machinery of the Senate Committee on the Judiciary, 95th Cong., 1st Sess. 55 (1978). See House REPORT, supra note 10, at 340, reprinted in 1978 U.S. CoDE CoNG. \& AD. News at 6296.

30 S. 2266, 95th Cong., 1st Sess., § 361 (1977), reprinted in, The Bankruptcy Reform Act of 1978: Hearings on S. 2266 and H.R. 8200 Before the Subcomm. on Improvements in the Judicial Machinery of the Senate Committee on the Judiciary, 95th Cong., 1st Sess. 55 (1978). See Senate Report, supra note 10, at 54, reprinted in 1978 U.S. Code Cong. \& AD. News at 5840.

so 11 U.S.C. $\$ 361(3)$ (Supp. V 1981) (prohibiting the use of an administrative priority); id. § 507(b) (creating superpriority). See In re Callister, 15 Bankr. 521, 526-28 (Bankr. D. Utah 1981), for a good discussion of the history of the superpriority.

4 See Senate Report, supra note 10, at 54, reprinted in 1978 U.S. Code Cong. \& Ad. 
might have resulted in a greater number of successful reorganizations than result under the Code as adopted.

A rule denying compensation for time value during the automatic stay has the same effect as does the Yale Express rule: both force secured creditors to accept less than full compensation for their secured claims. ${ }^{42}$ In the former case, the right to a payment today $^{43}$ is replaced by the promise of a payment of the same sum in the future. For the present payment and the promise of future payment to be equivalent, however, the sum promised for the future must be greater than the sum that would be paid today: if the secured creditor were paid today, he could invest the money and earn interest." The rule denying time value compensation is undercompensatory because it does not account for this lost interest. The Yale Express rule is undercompensatory because it does not increase the promised future payment to account for the risk that the reorganization will fail and leave the secured creditor with less than that for which he bargained. To argue that the Code allows

News at 5840 (rejecting the use of an administrative priority as adequate protection "because such protection is too uncertain to be meaningful"). The protection provided by an administrative priority is uncertain because the secured creditor may be unable to recover in full the amount of his secured claim. See supra text accompanying notes 34-36 (discussing the undercompensatory effect of Yale Express). The Yale Express rule had been criticized as impairing the interests of secured creditors. See Murphy, Restraint and Reimbursement: The Secured Creditor in Reorganization and Arrangement Proceedings, 30 Bus. Law. 15, 32-34 (1974) (criticizing the rule as an unconstitutional impairment of secured creditors' rights); Murphy, Use of Collateral in Business Rehabilitations: A Suggested Redrafting of Section 7-203 of the Bankruptcy Reform Act, 63 CazIF. L. REv. 1483, 1505 (1975) (the rule, as codified by the Commission on the Bankruptcy Laws of the United States, provides only "an ephemeral future priority as a device for avoiding present reality"); Rosenberg, Beyond Yale Express: Corporate Reorganization and the Secured Creditor's Right of Reclamation, 123 PA. L. Rzv. 509, 528-29 (1975) (the rule assumes successful reorganizations, which "does not accord with experience").

12 Under the Yale Express rule, the future payment depends, to the extent that an administrative priority replaces the lien on specific property, on the success of the reorganization; the secured creditor is not compensated for the risk of failure. In the case of the rule denying compensation for time value during the automatic stay, the secured creditor is assured of receiving the value of his collateral, without interest, regardless of the success of the reorganization, but he will not be compensated for the delay in payment.

is The contractual right of the secured creditor to foreclose, sell the property, and retain the proceeds up to the amount owed to him is in effect the right to payment today, for purposes of this analysis. The delay due to foreclosure and sale is small when compared to the delay resulting from the automatic stay and would occur in any event should the creditor later end up foreclosing rather than being paid under a reorganization plan.

4 One might consider separately the risk that the future payment will not be made, because risk is an independent component of the interest rate on any particular loan. See supra note 12. Market interest rates account for the risk of nonpayment, see R. BREALEY \& S. MYRRS, supra note 12, at 466-72; strictly speaking, therefore, the lost interest is all that need be considered. 
the court to deny secured creditors the time value of their claims during the automatic stay, therefore, would be to argue that Congress, in rejecting the Yale Express rule, primarily was concerned not with the undercompensation of secured creditors, but rather with the method of undercompensation. ${ }^{45}$

\section{Possible Arguments for Denying Time Value Compensation}

\section{A. Incompatibility of Reorganization and Full Compensation}

One goal of the Bankruptcy Code is to facilitate the reorganization of financially distressed businesses. ${ }^{46}$ The reason for doing so is to capture the surplus that exists when the assets of a debtor firm have greater value when used in the firm's operations than when sold to others. ${ }^{47}$ Holders of secured claims are not harmed (and holders of unsecured claims are distinctly benefited) by capturing this going-concern surplus. To illustrate, if the sum of all allowed secured claims against an entity is $\$ 100$ and the property securing such claims is worth $\$ 150$ when retained in the debtor's business, there is a going-concern surplus of $\$ 50$ that may be available to satisfy unsecured claims. ${ }^{48}$

1s The risk of undercompensation is not entirely eliminated by the rule permitting time value compensation during the automatic stay; some undercompensation would occur if the collateral was undervalued, see supra note 15 , or if the court failed to provide the creditor adequate protection against depreciation of his collateral. (A secured creditor is entitled to adequate protection against collateral depreciation under 11 U.S.C. $\$ 361$ (Supp. V 1981), which permits cash payments or substitute liens.) If these two sources of undercompensation are not present, however, the rule permitting time value compensation would eliminate the secured creditor's risk of recovering less than the dollar value of his secured claim as of the time of the petition.

16 Hughes, "Waivering Between the Profit and the Loss": Operating a Business During Reorganization Under Chapter 11 of the New Bankruptcy Code, 54 AM. BANKr. L.J. 45, 4749 (1980); Klein, The Bankruptcy Reform Act of 1978, 53 AM. BANKR. L.J. 1, 7 (1979).

67 See Senate Report, supra note 10, at 10, reprinted in 1978 U.S. Code Cong. \& Ad. News at 5796 ("A fair and equitable reorganization, as provided in the bill, is literally the last clear chance to conserve for [unsecured creditors and/or equity interests] values that corporate financial stress or insolvency have placed in jeopardy."). See also Coogan, Broude \& Glatt, Comments on Some Reorganization Provisions of the Pending Bankruptcy Bills, 30 Bus. LAw. 1149, 1154-55 (1975); Jackson, supra note 15, at 864-65 (creditors would prefer government-imposed bankruptcy distribution system to piecemeal liquidation via foreclosure because of possibility of increasing available pool of assets through reorganization or sale of business as going concern); infra note 53. Other purposes creditors may have in preferring reorganization over liquidation, such as possible future business with the reorganized entity or possible transfer of value from senior interests, are not legitimate if reorganization will reduce the value of the claims of parties objecting to the reorganization.

18 This illustration assumes that all secured creditors are undersecured and, for purposes of determining the value of the secured claims, that the collateral will be given the value it would bring if sold piecemeal. See 11 U.S.C. $\$ 506$ (a) (Supp. V 1981); infra note 53. 
Some courts have held that the policy of facilitating reorganization requires that no time value compensation be provided during the automatic stay because paying time value compensation would reduce the resources available to the firm to make a reorganization succeed..$^{49}$ But the policies of facilitating reorganization and compensating secured creditors for time value do not inherently conflict. Because of certain provisions in the Code intended to protect secured creditors, the courts correctly perceive a conflict, yet they incorrectly assume that the conflict should be resolved by denying secured creditors compensation for time value..$^{50}$

Secured creditors could be compensated completely in a reorganization by giving them shares in the reorganized entity, the shares having a present value on the date of the petition equal to the amount of the allowed secured claims. A court distributing such reorganization shares would protect the value of the secured creditors' first claim on the collateral securing their loans by discounting the value of the shares to account for the risk that the reorganization will fail. ${ }^{51}$ If the shares given to the secured creditors were not worth as much as the sum of the allowed secured claims ${ }^{62}$ two explanations could account for the shortfall. First, part of the value of the reorganized entity may have been diverted to junior claimants, in which case the shares should be readjusted to compensate secured creditors for the first claim they are forced to give up. Second, the value of the firm's assets in the hands of the debtor may in fact be less than their scrap value in the hands of others, in which case the court should recognize that reorganiza-

49 See, e.g., In re American Mariner Indus., 10 Bankr. 711, 713-14 (Bankr. C.D. Cal. 1981). Other courts have held that, during the stay, the "status quo" can be preserved for the creditors and the debtor by requiring protection only for the dollar amount of the secured claim at the time of the petition. See In re Pine Lake Village Apartment Co., 19 Bankr. 819, 827 (Bankr. S.D.N.Y. 1982); In re Wheeler, 12 Bankr. 908, 909-10 (Bankr. D. Mass. 1981); In re Born, 10 Bankr. 43, 48 (Bankr. S.D. Tex. 1981); In re Nixon Mach. Co., 9 Bankr. 316, 317-18 (Bankr. E.D. Tenn. 1981). Still other courts have held that the decision of whether to grant interest to secured creditors during the automatic stay must be made by balancing the harm to the secured creditors against the harm to the other interested parties. See In re First Century Trust Co., 12 Bankr. 204, 208 (Bankr. W.D. Tenn. 1981); General Motors Acceptance Corp. v. Anderson, 6 Bankr. 601, 610 (Bankr. S.D. Ohio 1980).

${ }^{B 0}$ See infra notes 51-63 and accompanying text.

B1 This is not the result in practice. Courts often are overly optimistic about the chance for successful reorganization, see Consolidated Rock Prods. Co. v. Du Bois, 312 U.S. 510, 525-27 (1941); Blum, The Law and Language of Corporate Reorganization, 17 U. CHI. L. REv. 565, 595-96 (1950), and as a result they tend to overvalue the reorganization shares given to creditors in lieu of allowing creditors to exercise their default rights. This causes inadequate compensation of secured creditors, to the benefit of subordinate interests.

${ }^{82} \mathrm{As}$, for example, if the shares given to the secured creditors in the illustration above, supra text accompanying note 48 , were worth $\$ 90$. 
tion is inappropriate and should liquidate the business so that the assets can go to higher value uses and the proceeds of liquidation can be paid to the creditors and invested in other businesses. $.^{53} \mathrm{Al}-$ though there may be some social advantages, such as retention of jobs, in maintaining insolvent businesses, these advantages are not a bankruptcy concern and there is no reason to force secured creditors to pay for them; in fact, it may be unconstitutional to force secured creditors to do $50 .{ }^{54}$

The Code does not follow the reorganization scheme described; rather than forcing secured creditors to accept reorganization shares that may be overvalued, the Code protects creditors by entitling them to deferred cash payments. ${ }^{55}$ In theory, when there

ss If all the debtor's assets sold piecemeal in liquidation are worth more than the company as a continuing business, there is no justification for maintaining the business. See Hughes, supra note 46 , at 48 ; Klein, supra note 46 , at 7.

The value of the allowed secured claims should be calculated "in light of the purpose of the voluation and the proposed disposition or use of such property." 11 U.S.C. § 506(a) (Supp. V 1981). Thus, in deciding whether to liquidate, the collateral should be given its liquidation value. There is inconsistency among court decisions as to the proper value to be given collateral in a reorganization proceeding. Compare In re Lackow Bros., Inc., 16 Bankr. 566, 569-70 (Bankr. S.D. Fla. 1981) (wholesale value proper for inventory valuation when determining whether secured creditor is adequately protected in Chapter 11 proceeding) with Roemelmeyer v. Walter E. Heller \& Co. (In re Lackow Bros.), 19 Bankr. 601, 604 (Bankr. S.D. Fla. 1982) (same case; "ongoing concern value" proper for inventory valuation when determining whether creditor is fully secured at time of petition). For an insightful discussion of proper valuation methods, see In re American Kitchen Foods, Inc., 2 Bankr. Ct. Dec. (CRR) 715, 719-22 (Bankr. D. Me. 1976), which, after discussing problems with "forced sale" liquidation value, adopts the "most commercially reasonable disposition" value.

s. See Louisville Joint Stock Land Bank v. Radford, 295 U.S. 555 (1935), where Justice Brandeis stated:

[T]he Fifth Amendment commands that, however great the Nation's need, private property shall not be thus taken even for a wholly public use without just compensation. If the public interest requires, and permits, the taking of property of individual mortgagees in order to relieve the necessity of individual mortgagors, resort must be had to eminent domain; so that, through taxation, the burden of relief afforded in the public interest may be borne by the public.

Id. at 602 .

Whether Radford would be followed today as a matter of constitutional law would depend on which creditor rights are taken. See supra note 24 and accompanying text. As a matter of policy, however, Justice Brandeis's argument remains compelling today, particularly when secured creditors are required to subsidize perceived public benefits. Some commentators have suggested that such public benefits be secured by incorporating tax credits into the law of reorganization. See, e.g., Gordainer, The Indubitable Equivalent of Reclamation: Adequate Protection for Secured Creditors Under the Bankruptcy Code, 54 AM. BANKR. L.J. 299, 329-37 (1980); Rosenberg, supra note 41, at 536-46.

Note that unsecured creditors may also be harmed by maintaining an insolvent business. If the debtor continues to incur losses, such losses reduce the estate available to satisfy unsecured claims.

ss See 11 U.S.C. $\$ 1129(\mathrm{~b})(2)(\mathrm{A})$ (Supp. V 1981) (a dissenting class of secured creditors 
is some going-concern surplus, this method of compensation should not impair the chance for successful reorganization: to pay the secured creditors, the debtor should be able to borrow funds against the value of his business as a going concern. In practice, lenders cannot predict perfectly the chance for successful reorganization, and they are hesitant to lend on the basis of the uncertain value of a firm in reorganization. ${ }^{\text {s6 }}$ As a result of the unavailability of such loans, the requirement of deferred cash payments may prevent a successful reorganization. ${ }^{57}$ Accordingly, the policies of promoting reorganization and of compensating secured creditors can conflict.

In every instance in which the Code explicitly resolves such conflicts, however, the resolutions demonstrate that Congress did not revere reorganizations as an end to be achieved at the expense of secured creditors. Specifically, three Code provisions in effect allow some reorganizations to fail rather than diminish the protection afforded secured creditors. Section 361(3) forbids use of the Yale Express remedy of forcing secured creditors to accept administrative priorities as adequate protection of their secured claims. ${ }^{58}$ Similarly, section $1129(\mathrm{~b})(2)(\mathrm{A})$ entitles a dissenting class of secured creditors to deferred cash payments rather than reorganization shares as compensation for their secured claims. ${ }^{59}$ Because these provisions require reorganizing debtors to provide secured creditors with cash or liens on specific property, or both, rather than with reorganization shares of uncertain value, ${ }^{60}$ some reorga-

is entitled to deferred cash payments rather than reorganization shares).

se See Blum, supra note 51, at 566-71 (discussing concept of reorganization value).

s7 This proposition is based on the argument that a company in reorganization, even though it cannot make cash payments to a secured creditor immediately, would be able to generate enough income later to compensate the creditor for waiting. That argument is inconsistent with the efficient markets theory, assuming that the market has as much information. as does the bankruptcy judge concerning prospects for successful reorganization. Efficient markets theory predicts that the reorganized entity should be able to sell an interest in its future income stream in order to generate the cash needed to meet the requirement of paying secured creditors immediately under the plan. For a general discussion of the efficient markets theory, see J. LourIe \& R. BrEaley, Modern Developments in. Investment MANAGEMENT 101-02 (1972). It is not clear whether the market and the courts operate with the same information, however. See generally supra note 56 and accompanying text.

ss 11 U.S.C. § 361(3) (Supp. V 1981); see supra notes 32-41 and accompanying text. An administrative priority is an unsecured claim. A dissenting class of unsecured claimants does not have the protection of the cash payment requirement, but can be paid off in "property," including reorganization shares. 11 U.S.C. $\S 1129(b)(2)(B)(i)$ (Supp. V 1981).

so 11 U.S.C. \& $1129(\mathrm{~b})(2)(\mathrm{A})$. This section also entitles secured creditors to time value compensation during cram-down, again revealing Congress's preference for the policy of fully compensating secured creditors over that of promoting reorganizations.

${ }^{\circ 0}$ Section 1129(b)(2)(A)'s requirement that a dissenting class of secured creditors be given cash payments rather than reorganization shares results in the reorganized entity's 
nized entities will fail when, but for cash flow problems engendered by the payments to secured creditors required by the Code, they might have succeeded. ${ }^{61}$ Finally, section $1129(\mathrm{a})(7)$ recognizes the right of secured creditors to compensation for time value once a reorganization plan is confirmed, ${ }^{62}$ again diminishing the funds available to make reorganization succeed.

In these three provisions, Congress chose to risk the failure of some reorganizations in order to provide full compensation to secured creditors. Although in section 361 Congress did not explicitly resolve the issue of time value compensation during the automatic stay $^{63}$ it would be incongruous with the other three provisions designed to protect secured creditors to assume that the policy of facilitating reorganization should prevail merely because Congress left the language of section 361 ambiguous.

The courts that rely on reorganization policy in denying time value compensation also fail to recognize that denying compensation for time value during the stay conflicts with the policy of the absolute priority rule, which underlies the reorganization provisions of the Code. The absolute priority rule entitles senior claimants to full payment before junior claimants receive anything. ${ }^{64} \mathrm{Ad}$

having to use cash to satisfy preexisting debt, leaving the entity with less cash for operating. Section 361(3)'s prohibition on demoting secured creditors to administrative claimants ensures that secured claims are protected under $\S 1129(\mathrm{~b})(2)(\mathrm{A})$ at the time of confirmation. See id. $\S \S 361(3), 1129(\mathrm{~b})(2)(\mathrm{A})$.

-1 But see supra note 57.

62 11 U.S.C. $\$ 1129$ (a)(7). See House REPORT, supra note 10, at 413 , reprinted in 1978 U.S. Code Cong. \& AD. NEws at 6369: "The property is to be valued as of the date of the plan, thus recognizing the time-value of money." Murel Holding suggests that denial of compensation for time value after confirmation would be unconstitutional. See supra text accompanying note 22 .

os 11 U.S.C. $\S 361$. See supra notes 10-14 and accompanying text.

-4 See House Report, supra note 10, at 413, reprinted in 1978 U.S. Code CoNG. \& AD. NEws at 6369: "The general principle of [\$1129(b)] permits confirmation notwithstanding non-acceptance by an impaired class if that class and all below it in priority are treated according to the absolute priority rule. The dissenting class must be paid in full before any junior class may share under the plan."

The absolute priority rule was first adopted as a governing principle in reorganization in Northern P. Ry. v. Boyd, 228 U.S. 482, 502-05 (1913). The rule was incorporated into the old Act in Case v. Los Angeles Lumber Prods., 308 U.S. 106, 115-19 (1939). The Code adopts the rule in the cram-down provisions. 11 U.S.C. § 1129(b) (Supp. V 1981). See In re Landau Boat Co., 8 Bankr. 436, 438 (Bankr. W.D. Mo. 1981); House RePoRT, supra note 10, at 413 , reprinted in 1978 U.S. Code Cong. \& AD. News at 6369; C. CYR, K. KLBE, H. Minkel, W. TAGGart, 5 Collier on BANKRUPTCY $/ 1129.03$ (15th ed. 1982) [hereinafter cited as 5 Collier]; 34 VAND. L. REv. 1727, 1730-31 (1981).

The rule has been modified to provide that consent by a class of secured creditors to less than full priority can bind dissenting members of that class. 11 U.S.C. $\$ 1129(\mathrm{a})(8)(B)$ (Supp. V. 1981). A dissenting class must receive cash payments, but a dissenting individual creditor may be forced to accept other "property" of the same nature as that accepted by 
hoc denial of time value compensation prevents full payment of secured creditors by, in effect, transferring wealth from secured creditors to unsecured creditors and to the debtor. ${ }^{65}$ The secured creditor suffers a loss of wealth because he is not compensated for losing the right he had under state law to foreclose on the collateral, sell it, and earn interest by investing the proceeds of the sale. The claims of the junior claimants increase in value because the debtor's estate retains property without paying for it, and the returns from the use of the collateral eventually are available for distribution to the junior class participating in the reorganization. ${ }^{86}$ By omitting such payments to secured claimants while retaining the property for the use of the debtor and the benefit of junior claimants, the rule denying time value compensation provides secured creditors with less than full compensation, and therefore is inconsistent with the absolute priority rule of reorganization.

the class. Such property might be an interest in the reorganized entity. See id. § 1129(a)(7) (dissenting creditor must receive "property"); id. $\$ 1129(\mathrm{~b})(2)(\mathrm{A})(\mathrm{i})(\mathrm{II})$ (dissenting class must receive "deferred cash payments"). There also may be a difference between the valuation standard used for the collateral in a cram-down on a dissenting class (presumably reorganization value) and that used to determine the liquidation claim of the individual dissenter (presumably liquidation value), because the individual is entitled to the amount he would have received in a liquidation. Id. $\S 1129(\mathrm{a})(7)$. The difference between the standards of $\S 1129(\mathrm{a})(7)$ and $\S 1129(\mathrm{~b})(2)(\mathrm{A})(\mathrm{i})(\mathrm{II})$ is not relevant in the many cases where each secured creditor is in a class by himself. See Trost, supra note 19 , at 1327 . In the remaining cases where the secured creditor dissents from the class vote, the result would be similar to the result of Yale Express, see supra notes 32-36 and accompanying text, but with one important difference: under the Code, the dissenting individual creditor must accept reorganization shares not because the court finds that they provide adequate compensation, but because the creditors of his own class agree to accept similar shares in compensation for their own interests.

${ }^{B}$ If time value compensation were always denied, secured creditors could prevent this wealth transfer by compensating themselves ex ante, see supra note 15 , but such a rule could undermine the social utility of secured credit, see supra note 17.

${ }^{38}$ A class of secured creditors in a reorganization plan must be given a promise of deferred cash payments if they do not accept another form of compensation. 11 U.S.C. $\S$ 1129(b)(2)(A)(i)(II) (Supp. V 1981); see supra note 64. As a result, the amount of their compensation is unaffected by the value of the debtor's estate. The junior classes, however, can be paid in shares in the reorganized entity, the value of which depends on the value of the debtor's estate. Secured creditors, in lieu of their right to be paid in cash, may choose to accept a plan granting them reorganization shares. 11 U.S.C. \$ 1129(a)(8) (Supp. V 1981). The fact that secured creditors may choose to accept shares in the reorganized entity does not affect the fact that the failure to compensate secured creditors for time value during the automatic stay is in effect a transfer to the unsecured creditors. If a secured creditor is aware that his secured claim will be reduced in value because the court will not require compensation for time value during the stay, he will choose between his diminished right to cash payments and the reorganization shares offered by the debtor. The debtor will also realize this and will reduce the value of the shares he offers. As a result, the secured creditor will go undercompensated and the beneficiaries of this undercompensation will be the unsecured creditors and the equity interests. 
B. Sections 502(b)(2) and 506(b)

Courts have relied on two other Code provisions, sections $502(\mathrm{~b})(2)^{67}$ and $506(\mathrm{~b}),{ }^{68}$ in holding that the Code prohibits protecting anything more than the dollar value of the secured claim as of the time of the petition. Neither section imposes any such prohibition.

Section 502(b)(2) disallows claims for "unmatured interest," but it does not prevent payment for time value compensation to secured creditors. First, section 502(b)(2) does not specifically address the treatment of claims arising during the stay; rather, it is part of a scheme to impose a uniform federal standard for allowance of claims against debtors in bankruptcy..$^{70}$ Thus, the section allows the court to avoid contract clauses that provide for interest acceleration and to protect creditors whose contracts do not provide for payment of principal in the event of bankruptcy. ${ }^{71}$ Once the bankruptcy claim has been brought into compliance with section 502(b)(2), however, nothing prevents other Code sections from providing creditors with interest on their claims. ${ }^{72}$

Second, the argument that section 502(b)(2) freezes the dollar amount of all interests at the time of the petition conflicts with another Code provision, section 726(a)(5). Section 726(a)(5) provides that unsecured creditors are allowed postpetition interest at the "legal rate" before the debtor is allowed to receive anything in a liquidation. ${ }^{73}$ If section $502(\mathrm{~b})(2)$ bars postpetition interest for

611 U.S.C. § 502(b)(2) (Supp. V 1981). See, e.g., In re BBT, 11 Bankr. 224, 231 n.12 (Bankr. D. Nev. 1981) ("Generally, there is no post-petition interest in an undersecured secured claim [11 U.S.C. § 502(b)(2)]." (brackets in original)).

a 11 U.S.C. $\S 506($ b) (Supp. V 1981). See, e.g., In re American Mariner Indus., 10 Bankr. 711, 712 (Bankr. C.D. Cal. 1981); General Motors Acceptance Corp. v. Anderson, 6 Bankr. 601, 608 (Bankr. S.D. Ohio 1980).

" 11 U.S.C. $\$ 502(b)(2)$ (Supp. V 1981).

${ }^{30}$ Under $i d$. \& 502, all claims are allowed under subsection (a) unless a party in interest objects. If such an objection is entered, the claim will be allowed or disallowed according to the terms of subsection (b). See House REPORT, supra note 10, at 352, reprinted in 1978 U.S. Code Cong. \& AD. News at 6308; Senate RePoRT, supra note 10, at 62 , reprinted in 1978 U.S. Code Cong. \& AD. News at 5848.

${ }^{11}$ For all contracts, interest stops running as of the date of the petition, and principal is accelerated, despite any contractual provisions to the contrary. See 11 U.S.C. § 502(b)(2) (Supp. V 1981). For statements that this principle is contained in $\S 502(\mathrm{~b})(2)$, see House REPORT, supra note 10, at 353, reprinted in 1978 U.S. CoDE ConG. \& AD. News at 6309; Senate Report, supra note 10, at 63, reprinted in 1978 U.S. Code Cong. \& AD. NEWS at 5849.

${ }^{72}$ See 11 U.S.C. $\$ 506$ (b) (Supp. V 1981) (allowing contractual interest to oversecured creditors while the stay is in effect); $i d . \$ 726(a)(5)$ (allowing legal-rate interest to unsecured claimants once principal has been paid).

72 Id. $\S 726(\mathrm{a})(5)$. 
secured creditors, then it would deny to secured creditors what section 726(a)(5) grants to unsecured creditors. There is neither language in the relevant Code sections nor any bankruptcy policy that supports treating secured creditors worse than unsecured creditors.

The second Code section upon which some courts have relied to deny time value compensation is section $506(\mathrm{~b})$, which provides that interest must continue to run under the contract of a fully secured creditor during the automatic stay. ${ }^{74}$ These courts have held that this section, by negative implication, prohibits payment of such interest to undersecured creditors. ${ }^{75}$ This reasoning, however, fundamentally misconstrues the role of adequate protection. The secured creditor has the right under his contract to payment of the debt or to foreclose on his collateral. The automatic stay denies both of these rights. The forced loan that results is governed by a different set of terms provided by the court through its interpretation of the adequate protection requirement. When viewed in this way, section 506(b), which provides for the continuation of some of the contractual rights of fully secured creditors, is an alternative to, not a limitation on, adequate protection. It does not affect the right of undersecured creditors to adequate protection.

\section{The Proper Rate of Compensation for the Thme Value of Secured Claims During the Automatic Stay}

The policies embodied in the Code and noted in the legislative history of the adequate protection requirement suggest that "adequate protection" includes time value compensation. One must still determine, however, the rate at which compensation should be provided. This part argues that it is consistent with the reason for granting interest during the automatic stay to use the market interest rate as opposed to the contract rate or state interest rate ceiling. ${ }^{76}$ The market rate fully compensates the secured creditor

"Id. § 506(b).

${ }^{75}$ See, e.g., In re Pine Lake Village Apartment Co., 19 Bankr. 819, 827 (Bankr. S.D.N.Y. 1982); In re American Mariner Indus., 10 Bankr. 711, 712 (Bankr. C.D. Cal. 1981); General Motors Acceptance Corp. v. Anderson, 6 Bankr. 601, 608 (Bankr. S.D. Ohio 1980).

76 The contract rate was the presumptive rate for cram-down interest in In re Smith, 4 Bankr. 12, 13 (Bankr. E.D.N.Y. 1980). The state interest rate ceiling was invoked in In re Crockett, 3 Bankr. 365, 368 (Bankr. N.D. Ill. 1980) (using state "general interest rate," as found in Act of May 24, 1879, § 4, IuL. REv. STAT. ch. 74, §4 (1979), later transferred to IlL. REv. StaT. ch. 17, §6404 (1981)). The rate provided by I.R.C. $\$ 6621$ (1976) has been relied on several times. See, e.g., In re Nite Lite Inns, 17 Bankr. 367, 372-73 (Bankr. S.D. Cal. 
for his loss due to the debtor's remaining in possession of the collateral and thereby gives him "in value essentially what he bargained for." "r7

The market rate fully compensates the secured creditor because, had he been allowed to foreclose and realize the collateral's value, he could have loaned the proceeds at the current market interest rate. Compensation at less than the market rate would result in a subsidy to the debtor's reorganization, the benefit of which would inure to the junior class of participating claimants. Such a subsidy is inconsistent with the absolute priority rule. ${ }^{78}$

Courts granting secured creditors interest at the market rate have measured the rate in several ways. ${ }^{79}$ Ideally, the court would provide the creditor with the "rate of interest which would be charged . . . by a creditor making a loan to a third party with similar terms, duration, collateral and risk." ${ }^{80}$ The difficulty in effecting this level of compensation is that the court, rather than the borrower and lender operating in an open market, must determine how factors peculiar to the transaction should affect the rate charged. Such effects are difficult to gauge outside of the market, and, as a result, the court's determination is likely to be inaccurate. ${ }^{81}$

The courts could avoid such case-specific evaluations by adopting a fixed interest rate equal to the sum of a broad measure of market interest rates, such as the interest rate for six-month U.S. Treasury Bills, plus a fixed premium to account for the risk of lending to a business in bankruptcy. ${ }^{82}$ Although this rate fails to account for the individual factors that borrowers and lenders

1982); In re Johnson, 8 Bankr. 503, 506 (Bankr. S.D. Tex. 1981); In re Ziegler, 6 Bankr. 3, 6 (Bankr. S.D. Ohio 1980). In In re Lum, 1 Bankr. 186, 186 (Bankr. E.D. Tenn. 1979), the court selected a rate lying between the contract rate and the state legal rate.

77 House RePoRT, supra note 10, at 339, reprinted in 1978 U.S. Code Cong. \& AD. News at 6295.

${ }^{78}$ See supra notes 64-66 and accompanying text.

70 In In re Victory Constr. Co., 9 Bankr. 570, 574 (Bankr. C.D. Cal. 1981), the bankruptcy court simply "found" a particular rate (18\%) to be appropriate. In In re Landmark at Plaza Park, Ltd., 7 Bankr. 653, 657 (Bankr. D.N.J. 1980) (citing 5 Collrer, supra note 64, 81129.03 (15th ed. 1980)), the court awarded interest at the rate "which could be charged or obtained by a creditor making a loan to a third party with similar terms, duration, collateral, and risk." In In re Thomas Parker Enters., 8 Bankr. 207, 212 (Bankr. D. Conn. 1981), the court set the rate at $3 \%$ over the prime rate.

so In re Landmark at Plaza Park, Ltd., 7 Bankr. 653, 657 (Bankr. D.N.J. 1980) (citing 5 Collier, supra note 64, II 1129.03 (15th ed. 1980)).

see Jackson, supra note 15, at 874-75.

82 This is similar to the technique used by the court in In re Thomas Parker Enters., 8 Bankr. 207, 212 (Bankr. D. Conn. 1981) (3\% over prime). 
would consider when negotiating a contractual rate of interest, it does have the advantage of certainty. In addition, lenders, who know in advance the rate of compensation they will receive if the debtor files in bankruptcy, can account for individual factors when making the original loan.

In calculating the risk premium, the courts should place the lender in no better position than he would have been in had he taken the Code's protection as a given and negotiated the rate of compensation in bankruptcy himself. Hence, the risk premium should reflect the fact that, under the Code, the secured creditor is entitled to a superpriority on the unencumbered assets of the estate in the event "adequate protection" proves insufficient to protect the appraised value of the creditor's secured claim. ${ }^{83}$ Since the Code's superpriority provides the secured creditor with more protection than does a security agreement, ${ }^{84}$ the risk premium in bankruptcy should be lower than that which the secured creditor would charge if the Code's protection were not given.

\section{ConcLusion}

The filing of a bankruptcy petition in effect terminates the contractual relationship between the creditor and the debtor. Through the mechanism of adequate protection, the bankruptcy law provides a substitute set of terms under which the debtor is allowed to retain property during the automatic stay without impairing the rights of the creditor. The Code does not provide an explicit answer to the question of whether the debtor may retain collateral without compensating secured creditors for the time value of their claims. The legislative history and underlying policies of the Code, however, support granting time value compensation. Although granting time value compensation may reduce the funds available to effect successful reorganizations, examination of

s3 See In re Callister, 15 Bankr. 521, 525-30 (Bankr. D. Utah 1981) (interpreting 11 U.S.C. \& 507(b) (Supp. V 1981) to entitle a secured creditor to a superpriority on unencumbered assets in the event adequate protection proves insufficient), appeal dismissed, 673 F.2d 305 (1982).

84 If the creditor's collateral proves to be worth less than the amount of the loan outstanding, his recourse under the contract is either an unsecured claim for the deficiency or nothing, depending on the terms of the contract. In a reorganization, a nonrecourse secured claim, if undersecured, gives rise to a deficiency claim for the balance of the debt in some circumstances. 11 U.S.C. $\& 1111$ (b)(1)(A) (Supp. V 1981). If the protection provided during the automatic stay proves to be less than adequate, the creditor's "superpriority" places him ahead of all claims other than those of other secured creditors, including claims for administrative expenses. $I d$. $\S 507(\mathrm{~b})$. 
the Code reveals that reorganizations are not to be implemented at the expense of forcing secured creditors to accept less than they would receive in liquidation.

The policies that lead a court to grant secured creditors time value compensation during the automatic stay should govern the court's choice of a compensation rate. Accordingly, the rate should be the market rate for a new loan to the debtor in the amount of the secured claim. Since determination of the market rate may be cumbersome, the courts might effect savings in administrative costs by setting the compensation rate in all cases equal to some broad market measure, such as the six-month Treasury Bill rate, plus a fixed premium to account for the additional risk of lending to a debtor in bankruptcy.

Thomas O. Kelly III 